\title{
Pengembangan E-Modul Asam Basa Berbasis Discovery Learning Untuk Kelas XI SMA/MA
}

\author{
Trihanto Setiadi ${ }^{1)}$ dan Rahadian Zainul ${ }^{2)^{*}}$ \\ 1,2) Jurusan Kimia, Fakultas Matematika Ilmu Pengetahuan Alam, Universitas Negeri \\ Padang, Indonesia \\ Author Corespondent: rahadianzmsiphd@gmail.com
}

\begin{abstract}
This research is aimed to develop the e-modul of acid base based of discovery learning.. The type of research used is research and development or Research and Development $(R \& D)$. The development model used is a 4-D model (four-D models) which consists of 4 stages, namely: define, design, develop and disseminate. This research is limited to the stage of development, namely the validity and practicality test. The research instrument used was a questionnaire of validity and practicality. The E-Module was validated by 5 validators while the practicality test was carried out by 3 chemistry teachers and 27 XI grade students of MIA SMA UNP Laboratorium UNP. Data from the validity and practicality test results were analyzed using the cohen kappa formula. Based on the results of the study, it was found that the average kappa moment of validity test was 0,953 with a very high validity category and the average kappa moment of teacher practicality was 0,921 and students were 0,883 with a very high practicality category. Thus, it was concluded that acid base e-module based on discovery learning was produced for valid and practical high school students.
\end{abstract}

Keywords: E-Module, Discovery Learning, Acid Base, Research and Development, 4-D Models.

\section{PENDAHULUAN}

Di dalam proses pembelajaran seperti guru, siswa dan lingkungan dapat mempengaruhi untuk tercapainya tujuan pembelajaran. Faktor penunjang untuk tercapainya tujuan pembelajaran adalah dengan menggunakan bahan ajar. Hal ini berkaitan dengan menggunakan bahan ajar yang bervariasi dan tepat dapat meningkatkan motivasi belajar di dalam proses pembelajaran. Tujuan pendidikan akan tercapai jika kualitas pendidikan tercapai, dan salah satu untuk memperbaiki kualitas pendidikan yaitu dengan meningkatkan kualitas pembelajaran di sekolah. Ada beberapa faktor pendukung untuk terwujudnya proses pembelajaran yang berkualitas untuk tercapainya tujuan pendidikan yaitu dengan menggunakan atau memanfaatkan perkembangan teknologi dalam proses pembelajaran (Budiana, 2015: 60).

Pada tingkat SMA di kelompok peminatan MIPA, mata pelajaran khususnya kimia merupakan mata pelajaran yang penting diajarkan sebagai mata pelajaran tersendiri. Kimia adalah ilmu yang mengkaji sifat zat dan bagaimana zat itu bereaksi dengan zat lain (Chang, 2005: 6). Salah satu tujuan mata pelajaran kimia adalah menerapkan konsep-konsep kimia untuk menyelesaikan masalah dalam kehidupan sehari-hari dan teknologi (Kemendikbud, 2013).

Asam basa adalah materi yang terdapat di kelas XI SMA. Materi asam basa berisi pengetahuan yang berdimensi faktual, konseptual, dan prosedural. Asam 
basa merupakan materi prasyarat untuk mempelajari materi selanjutnya seperti larutan penyangga. Jika siswa belum paham pada materi itu, maka siswa akan sulit untuk memahami materi selanjutnya. Oleh karena itu, materi ini membutuhkan pemahaman yang lebih mendalam.

Berdasarkan hasil wawancara dengan guru dan pengisian angket oleh siswa diperoleh hasil (1) materi asam basa masih kurang dipahami oleh beberapa siswa, (2) bahan ajar yang digunakan di sekolah adalah buku cetak, lembar kerja siswa, dan powerpoint, (3) kurang pahamnya siswa belajar menggunakan bahan ajar yang disediakan oleh guru. Hal ini dikarenakan bahan ajar yang digunakan belum menampilkan tahapan model discovery learning. Oleh karena itu perlu dikembangkan bahan ajar dalam bentuk modul berbasis discovery learning untuk meningkatkan pemahaman siswa.

Dengan adanya perkembangan teknologi yang semakin pesat sangat memungkinkan peranan TIK dalam proses kegiatan belajar mengajar untuk mencapai tujuan pembelajaran dengan hasil yang lebih baik. Hasil dari perkembangan teknologi saat ini dibidang pendidikan salah satunya adalah memodifikasi modul cetak menjadi format elektronik atau yang dikenal e-modul. Menurut Kemendikbud (2017) e-modul adalah bahan belajar mandiri untuk proses pembelajaran yang disusun secara sistematis dan disajikan dalam format elektronik.

Penelitian Dahlan (2016) melaporkan bahwa e-modul pada materi sistem peredaran darah yang valid dan praktis dapat membantu siswa dalam memahami materi. Adanya animasi-animasi dan video dapat menambah minat siswa dalam belajar sehingga memberikan pengalaman belajar yang nyata dan menarik. E-modul juga telah banyak dikembangkan yang telah diuji kevalidan dan kepraktisannya (Farenta, dkk (2016), Zulkarnain, dkk (2015), Nurzaman, dkk (2013), Syamsurizal, dkk (2015). Penelitian yang dilakukan oleh Oktavia, dkk (2018) tentang pengenalan dan pengembangan e-modul bagi guru-guru anggota MGMP kimia dan biologi kota Padang Panjang bahwa guru tertarik untuk membuat dan menggunakan e-modul dalam proses pembelajaran. Emodul ini memiliki design yang menarik dan efektif digunakan dalam pembelajaran. Penelitian oleh Chairi, dkk (2016) tentang pengembangan LKS dengan pendidikan saintifik berbasis discovery learning pada materi hukum dasar kimia kelas $\mathrm{X}$ SMA/MA bahwa validitas dan praktikalitas bahan ajar tersebut sangat tinggi. Kemudian penelitian oleh Sepriandi, dkk (2016) tentang pengembangan LKS dengan pendekatan saintifik berbasis discovery learning pada materi asam basa untuk pembelajaran kimia kelas XI SMA/MA bahwa Validitas dan praktikalitas LKS tersebut sangat tingi. Penelitian yang dilakukan oleh Jannah, dkk (2017) tentang pengembangan media pembelajaran asam basa menggunakan aplikasi android berbasis chemistry triangle KELAS XI SMA/MA bahwa media yang dihasilkan memiliki kevalidan dan kepraktisan yang sangat tinggi.

Berdasarkan permasalahan tersebut, penulis ingin mekukan penelitian untuk mengembangkan bahan ajar dalam bentuk e-modul berbasis discovery learning dengan judul "Pengembangan E-Modul Asam Basa Berbasis Discovery Learning Untuk Kelas XI SMA/MA”

\section{METODE PENELITIAN}

Jenis penelitian yang digunakan adalah penelitian dan pengembangan atau Research and Development $(R \& D)$. Model pengembangan yang digunakan ini adalah 
model 4-D (four D models) yang terdiri atas 4 tahap, yaitu pendefinisian (define), perancangan (design), pengembangan (develop), dan penyebaran (dissiminate). Penelitian ini hanya dilakukan sampai uji validitas dan uji praktikalitas terhadap emodul yang dikembangkan. Subjek penelitian ini adalah 2 orang dosen kimia FMIPA UNP, 3 orang guru kimia, dan 27 orang siswa kelas XI MIA SMA Pembangunan Laboratoriun UNP.

Tahap pendefinisian (define) dilakukan dengan cara penetapan dan pendefinisian syarat-syarat dalam pembelajaran. Tahap ini diawali dengan menganalisis tujuan dari batasan materi dan bahan materi berdasar-kan kurikulum 2013 revisi 2017. Tahap ini meliputi: (a) tahap analisis ujungdepan dilakukan dengan wawancara dengan guru kimia; (b) analisis siswa dilakukan dengan penyebaran angket kepada siswa yang bertujuan untuk memahami karakteristik siswa; (c) analisis tugas dilakukan dengan menganalisis kompetensi dasar (KD) 3.10 dan 4.10 yang selanjutnya dilakukan perumusan indikator sesuai dengan KD tersebut; (d) analisis konsep dilakukan dengan cara mengidentifikasi konsep-konsep utama pada materi asam basa; (e) analisis tujuan pembelajaran dilakukan dengan pengubahan hasil analisis tugas dan analisis konsep ke dalam tujuan pembelajaran yang akan dicapai oleh siswa.

Pada tahap perancangan (design) bertujuan untuk merancang e-modul asam basa berbasis discovery learning. Perancangan terdiri dari: cover, petunjuk belajar, peta konsep, lembar kegiatan, lembar kerja siswa, lembaran tes, kunci jawaban, dan glosarium.

Pada tahap pengembangan (develop) bertujuan untuk menghasilkan e-modul asam basa berbasis discovery learning yang valid dan praktis digunakan untuk proses pembelajaran. Tahap ini meliputi: (a) uji validitas bertujuan untuk mengungkapkan tingkat validitas dari e-modul asam basa berbasis discovery learning yang telah dikembangkan; (b) revisi untuk memperbaiki bagian e-modul asam basa berbasis discovery learning yang dianggap kurang tepat oleh validator sebelum produk diuji coba; (c) uji coba bertujuan untuk mengetahui tingkat praktikalitas e-modul asam basa berbasis discovery learning yang dikembangkan. Penelitian ini hanya dilakukan hanya sampai tahap develop karena keterbatasan waktu.

Instrumen yang digunakan adalah angket validasi dan praktikalitas. Lembar validasi digunakan untuk menilai validitas e-modul asam basa berbasis discovery learning yang dikembangkan. Lembar validasi ini ditu-jukan kepada dosen FMIPA UNP dan guru kimia. Lembar praktikalitas digunakan untuk mengetahui tingkat praktikalitas pemakaian e-modul asam basa berbasis discovery learning yang dikembangkan. Lembar praktikalitas ini ditujukan kepada guru kimia dan siswa.

Data yang diperoleh dianalisis menggunakan formula kappa Cohen di bawah ini.

$$
\text { momen kappa }(\kappa)=\frac{\rho_{o}-\rho_{e}}{1-\rho_{e}}
$$

Keterangan:

$\mathrm{K}=$ momen kappa

$\rho_{o}=$ Proporsi yang terealisasi

$\rho_{e}=$ Proporsi yang tidak terealisasi

Tabel 1. Kategori Keputusan berdasarkan Momen Kappa (Bolaugh, 2008)

\begin{tabular}{|c|c|}
\hline Interval & Kategori \\
\hline $0,81-1,00$ & Sangat tinggi \\
\hline $0,61-0,80$ & Tinggi \\
\hline $0,41-0,60$ & Sedang \\
\hline $0,21-0,40$ & Rendah \\
\hline $0,01-0,20$ & Sangat rendah \\
\hline$<0,00$ & Tidak valid \\
\hline
\end{tabular}




\section{HASIL DAN PEMBAHASAN}

1. Tahap Pendefinisian (Define)

a. Analisis ujung depan

Analisis ujung depan dilakukan dengan cara wawancara dengan guru kimia. Berdasarkan hasil wawancara dengan guru kimia di SMA Pembangunan Laboratorium UNP diperoleh hasil sebagai berikut: (1) terdapat beberapa siswa yang kurang paham terhadap materi asam basa; (2) bahan ajar yang digunakan berupa PPT, LKS, dan buku paket, (3) bahan ajar belum termuat tahapan-tahapan discovery learning.

b. Analisis siswa

Analisis siswa dilakukan dengan pengisian angket oleh siswa SMA Pembangunan Laboratoriun UNP. Siswa SMA dikategorikan sebagai remaja dengan usia 15-17 tahun. Berdasarkan teori perkembangan kognitif piaget siswa SMA dimulai dari usia 15-17 tahun termasuk ke dalam tahap operaional formal (Omrod, 2014: 43-47). Tahap operasional formal ini ditandai dengan kemampuannya untuk berfikir secara abstrak, menalar secara logis dan menarik kesimpulan dari informasi yang tersedia. Berdasarkan hasil angket yang diperoleh keseluruhan siswa sudah bisa mengoperasikan komputer atau laptop.

c. Analisis tugas

Berdasarkan silabus kurikulum 2013 revisi 2017 materi asam basa terdapat pada KD 3.10 dan 4.10. KD 3.10 Menjelaskan konsep asam dan basa serta kekuatannya dan kesetimbangan pengionannya dalam larutan; 4.10 Menganalisis trayek perubahan $\mathrm{pH}$ beberapa indikator yang diekstrak dari bahan alami melalui percobaan. Berdasarkan KD tersebut dirumuskan indikator pencapaian kompetensi yaitu 1) Menjelaskan sifat larutan berdasarkan konsep asam basa menurut Arrhenius, Bronsted-Lowry dan Lewis, 2) Membedakan kekuatan asam kuat, asam lemah, basa kuat dan basa lemah, 3) Menghitung pH larutan asam dan basa, 4) Menghubungkan asam lemah dengan asam kuat serta basa lemah dengan basa kuat untuk mendapatkan derajat ionisasi dan tetapan ionisasi, 5) Menentukan sifat larutan asam basa dengan menggunakan kertas lakmus dan indikator alam.

d. Analisis konsep

Berdasarkan analisis konsep dapat ditentukan atribut-atribut konsep yang dipelajari pada materi asam basa. Konsep-konsep utama pada materi asam basa adalah larutan, larutan asam, asam kuat, asam lemah, larutan basa, basa kuat, basa lemah, asam Arrhenius, basa Arrhenius, asam Bronsted-Lowry, basa Bronsted-Lowry, asam konjugasi, basa konjugasi, asam Lewis, basa Lewis, kekuatan asam, kekuatan basa, konstanta ionisasi asam, konstanta ionisasi basa, $\mathrm{pH}, \mathrm{pOH}$, dan indikator. Setelah konsep dianalisis dapat dilihat hubungan antar konsep dalam bentuk peta konsep.

e. Analisis tujuan pembelajaran

Berdasarkan IPK yang telah didapatkan, dapat ditentukan tujuan pembelajaran. Tujuan pembelajaran asam basa yaitu melalui model discovery learning dengan 6 tahap (stimulation, problem statement, data collection, data processing, verification, generalization) dengan strategi belajar mandiri dengan berbasis 
komputer peserta didik diharapkan mampu menjelaskan sifat larutan berdasarkan konsep asam basa menurut Arrhenius, Bronsted-Lowry, dan Lewis, menganalisis sifat larutan berdasarkan $\mathrm{pH}$ larutan, membedakan kekuatan asam kuat, asam lemah, basa kuat, dan basa lemah, menghitung $\mathrm{pH}$ larutan asam dan basa, menghubungkan derajat keasaman $(\mathrm{pH})$ dengan derajat ionisasi, dan tetapan kesetimbangan asam dan basa serta, menentukan sifat larutan asam dan basa dengan menggunakan kertas lakmus dan indikator alam.

2. Tahap Perancangan (Design)

Pada tahap perancangan (design) ini dilakukan desain e-modul asam basa berbasis discovery learning yang akan dikembangkan. E-modul ini disusun berdasarkan komponen-komponen emodul yang diuraikan dalan Kemendikbud (2017: 7) yaitu: cover, petunjuk belajar, peta konsep, lembar kegiatan, lembar kerja siswa, lembaran tes, kunci jawaban, dan glosarium. Pada lembaran kerja disusun berdasarkan tahapan-tahapan discovery learning. Emodul ini dibuat dengan menggunakan aplikasi Microsoft Publisher 2013, Adobe Flash CS6, Wondershare Filmora, Format Factory, dan Kvisoft Flipbook Maker.

\section{Tahap Pengembangan (Develop)}

a. Uji validasi

Uji validitas merupakan penilaian terhadap rancangan suatu produk. Aspek penilaian dibagi menjadi beberapa komponen yang terdiri dari komponen isi, komponen kebahasaan, komponen penyajian, dan komponen kegrafikaan (Depdiknas, 2008: 28). E-modul asam basa berbasis discovery learning diberi penilaian oleh 2 orang dosen dan 3 orang guru kimia. Penilaian lima orang validator ini didasarkan pada pendapat Sugiyono (2013: 172) yang menyatakan bahwa untuk menguji validitas, dapat digunakan pendapat ahli (judgement experts) yang jumlahnya minimal tiga orang. Hasil yang diperoleh dapat dilihat pada Gambar 1.

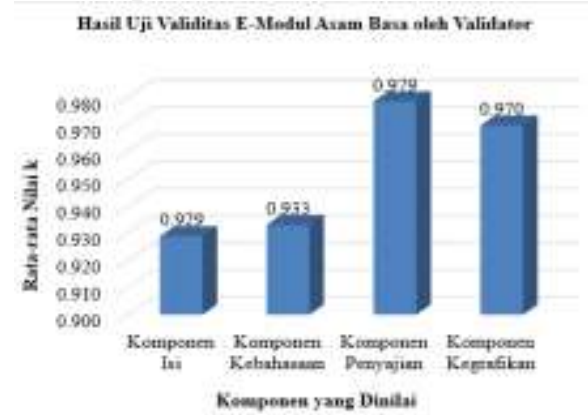

Gambar 1. Hasil analisis data validitas oleh validator

Komponen isi e-modul asam basa berbasis discovery learning memiliki rata-rata momen kappa sebesar 0,929 dengan kategori sangat tinggi. Hal ini menunjukkan bahwa emodul yang dikembangkan telah sesuai dengan tuntutan Kompotensi Inti (KI), Kompetensi Dasar (KD), yaitu KD 3.10 dan KD 4.10 pada Silabus Kurikulum 2017. Sesuai dengan pendapat Purwanto (2006: 138) bahwa aspek keyakan isi meliputi kesesuaian materi yang terdapat dalam e-modul dengan KI, $\mathrm{KD}$, tujuan pembelajaran yang ingin dicapai dan materi yang diberikan sesuai dengan kemampuan siswa.

Komponen kebahasaan memiliki nilai rata-rata momen kappa emodul asam basa berbasis discovery learning yang dikembangkan sebesar 0.933 dengan kategori sangat tinggi. Hal ini berarti bahasa yang digunakan 
pada e-modul yang dikembangkan telah sesuai dengan kaidah Bahasa Indonesia yang baik dan benar, komunikatif dan mudah dipahami. Depdiknas (2017: 7) menyatakan bahwa e-modul yang baik menggunakan kalimat yang sederhana sehingga informasi yang disampaikan jelas dan bersifat user friendly (bersahabat dengan pema-kainya). Penggunaan bahasa yang komunikatif dan sederhana membuat modul mudah dimengerti, sehingga dapat meningkatkan pemahaman konsep dan minat belajar peserta didik (Lasmiyati, 2014).

Komponen penyajian memiliki nilai rata-rata momen kappa e-modul asam basa berbasis discovery learning yang dikembangkan sebesar 0.979 dengan kategori sangat tinggi. Hal ini berarti e-modul asam basa berbasis discovery learning yang telah dikembangkan dibuat sesuai dengan indikator dan tujuan pembelajaran yang telah dirumuskan. Penyajian e-modul disusun berdasarkan tahapan model discovery learning. Pada tahapan tersebut terdapat gambar, video, animasi dan pertanyaan-pertanyaan yang berhubungan dengan materi yang dibahas. Hal ini bertujuan agar siswa lebih termotivasi dalam belajar serta untuk meningkatkan pemahaman siswa terhadap materi tersebut. Pada emodul ini juga dilengkapi dengan soal evaluasi. Soal evaluasi merupakan alat yang digunakan untuk mengukur keberhasilan atas ketercapaian tujuan pembelajaran yang telah dirumuskan (Suryosubroto, 1993). Pada soal evaluasi ini, nilai/hasil akhir dapat dilihat langsung oleh siswa setelah menjawab semua pertanyaanpertanyaan yang ada pada soal tersebut.

Komponen kegrafikan memiliki nilai rata-rata momen kappa emodul asam basa berbasis discovery learning yang telah dikembangkan sebesar 0.970 dengan kategori sangat tinggi. Hal tersebut menunjukkan bahwa e-modul asam basa berbasis discovery learning yang dikembangkan memiliki lay out, tata letak, video, gambar, desain tampilan dan ukuran huruf yang jelas secara keseluruhan telah menarik. Adanya modul yang dibuat semenarik mungkin dapat memotivasi peserta didik untuk membaca bahan materi dalam pembelajaran (Lestari, 2013). Pada e-modul juga dilengkapi dengan gambar-gambar yang mendukung dengan materi asam basa. Penggunaan gambar dapat menambah daya tarik bahan ajar dan dapat mengurangi kebosanan siswa dalam mempelajarinya. Selain itu juga terdapat video yang relevan dengan materi yang disajikan. Ini berfungsi untuk meningkatkan pemahaman dan motivasi belajar siswa.

Hasil validasi yang diperoleh dari validator selanjutnya dilakukan beberapa revisi terhadap rancangan emodul asam basa yang dikembangkan berdasarkan saran dari validator.

b. Revisi

Tahap revisi bertujuan untuk memperbaiki bagian e-modul asam basa berbasis discovery learning yang dianggap kurang tepat oleh validator sebelum produk diuji coba. E-modul yang telah direvisi selanjutnya diberikan kepada validator untuk didiskusikan kembali. Revisi selesai apabila e-modul asam basa berbasis 
discovery learning yang dikembangkan dinyatakan valid oleh validator. Beberapa komponen emodul asam basa berbasis discovery learning yang disarankan direvisi oleh validator: 1) menghilangkan tambahan informai yang terdapat pada lembar kegiatan, 2) pada video lebih diperjelas produk dan reaktan, 3) penulisan kata tanya, 4) penambahan materi memperkirakan trayek $\mathrm{pH}$.

c. Uji coba

Kepraktisan e-modul asam basa berbasis discovery learning yang dikembangkan dilihat dari keterpakaian produk pada hasil uji coba terbatas di lapangan. Hasil praktikalitas oleh guru dan siswa dapat dilihat pada Gambar 2.

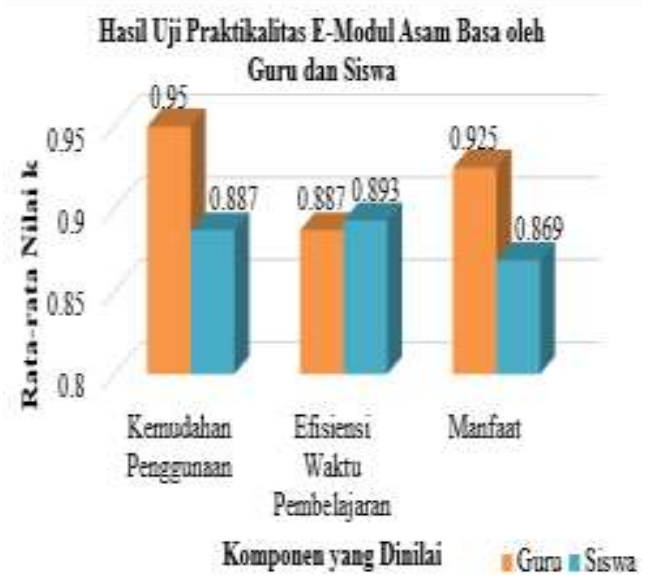

Gambar 2. Hasil analisis data praktikalitas oleh guru dan siswa

Momen kappa dari angket respon guru sebesar 0.921 (dari angket respon guru) dengan kategori kepraktisan sangat tinggi (sangat praktis) dan 0.883 (dari angket respon siswa) dengan kategori kepraktisan sangat tinggi.

\section{KESIMPULAN DAN SARAN}

\section{Kesimpulan}

Berdasarkan penelitian yang telah dilakukan, dapat disimpulkan sebagai berikut.

1. Dihasilkan E-Modul asam basa berbasis discovery learning untuk kelas XI SMA/MA dengan model pengembangan 4-D.

2. E-Modul asam basa berbasis discovery learning untuk kelas XI MA/MA yang dihasilkan mempunyai kevalidan dan kepraktisan sangat tinggi.

\section{Saran}

Berdasarkan hasil penelitian dan kesimpulan yang diperoleh, maka disarankan beberapa hal sebagai berikut ini.

1. Bagi guru direkomendasikan e-modul ini dapat menjadi salah satu alternatif bahan ajar pada materi asam basa dalam proses pembelajaran.

2. Sekolah yang melakukan pembelajaran menggunakan e-modul, sebaiknya memiliki Laboratorium Komputer yang dapat digunakan untuk penelitian. Jika tidak ada, pastikan siswa membawa laptop saat penelitian.

3. Bagi peneliti selanjutnya untuk melakukan uji efektivitas e-modul yang telah dikembangkan.

\section{DAFTAR PUSTAKA}

Boslaugh, S., dan Paul A. W. 2008. Statistics in a Nutshell, a desktop quick reference. Beijing, Cambridge, Famham, KÖln, Sebastopol, Taipei, Tokyo: O'reilly.

Budiana, H.R., Sjafirah, N.A., dan Bakti, I. 2015. Pemanfaatan Teknologi Informasi dan Komunikasi dalam Pembelajaran bagi Para Guru SMPN 2 Kawali Desa Citeureup Kabupaten Ciamis. Jurnal Aplikasi Ipteks untuk 
Masyarakat. Volume 4, Nomor 1, Halaman 59-62.

Chairi, Ikhwan, Ellizar, and Rahadian Zainul., 2018. "Pengembangan LKS dengan Pendekatan Saintifik Berbasis Discovery Learning Pada Materi Hukum Dasar Kimia untuk pembelajaran Kelas X SMA/MA". INA-Rxiv. September 19. doi:10.31227/osf.io/xnbtv.

Chang, Raymond. 2005. Konsep-konsep Inti Edisi 3 Jilid 1. Jakarta: Erlangga.

Depdiknas. 2008. Panduan Pengembangan Bahan Ajar. Jakarta: Departemen Pendidikan Nasional Direktorat Jenderal Manajemen Pendidikan Dasar dan Menengah Direktorat Pembinaan Sekolah Menengah Atas.

Farenta, Arvi Sekar., Sulton., dan Punaji Setyosari. 2016. Pengembangan Emodule Bebasis Problem Based Learning Mata Pelajaran Kimia untuk Siswa Kelas X SMA Negeri 8 Malang. Jurnal Pendidikan. Volume 1, Nomor 6, Halaman 1159-1168.

Kemendikbud. 2017. Panduan Praktis Penyusunan E-Modul Pembelajaran. Jakarta: Direktorat Pembinaan SMA.

Lasmiyati. 2014. Pengembangan Modul Pembelajaran untuk Meningkatkan Pemahaman Konsep dan Minat SMP. Jurnal Pendidikan Matematika. Volume 9, Nomor 2, Halaman 161174.

Lestari, Eka. Dan Abdur Rahman As'ari. A.R. 2013. Pengembangan Modul Pembelajaran Soal Cerita Matematika Kontekstual Berbahasa Inggris untuk Siswa Kelas X. Artikel. Malang: Universitas Negeri Malang.

Nurzaman, Nevi., Ida Farida Ch., dan Ratih Pitasari. 2013. E-Module Pembelajaran Minyak Bumi Berbasis Lingkungan untuk Mengembangkan Kemampuan Literasi Kimia Siswa.
Prosiding Simposium Nasional Inovasi dan Pembelajaran Sains. Halaman 164-167.

Omrod, J. 2014. Psikologi Pendidikan Edisi ke-Enam. Jakarta: Erlangga.

Sepriandi, Pobby, Ellizar, and Rahadian Zainul. 2018. "Pengembangan LKS dengan Pendekatan Saintifik Berbasis Discovery Learning Pada Materi Asam Basa untuk pembelajaran Kelas XI SMA/MA”. INA-Rxiv. September 19. doi:10.31227/osf.io/5cb3h.

Suarsana, I. M., dan G. A. Mahayukti. 2013. Pengembangan E-Modul Berorientasi Pemecahan Masalah Untuk Meningkatkan Keterampilan Berpikir Kritis Mahasiswa. Jurnal Nasional Pendidikan Teknik Informatika. Volume 2, Nomor 2, Halaman 193-200.

Sugiyono. 2013. Metode Penelitian Pendidikan. Bandung: Alfabeta.

Suryosubroto, B. 1993. Sistem Pengajaran dengan Modul. Yogyakarta: Bina Aksara.

Syamsurizal., Haryanto., Novi Chairani. 2015. Pengembangan E-Modul Berbasis Keterampilan Proses Sains pada Materi Kesetimbangan Kimia untuk Tingkat SMA. Prosiding SEMIRATA 2015 bidang MIPA BKSPTN Barat. Halaman 655-661.

Trianto. 2012. Model Pembelajaran Terpadu: Konsep, Strategi, dan Implementasinya dalam Kurikulum Tingkat Satuan Pendidikan (KTSP). Jakarta: Bumi Aksara.

Zainul, Rahadian, Budhi Oktavia, Guspatni, and Ananda Putra. 2018. "Pengenalan dan Pengembangan EModul Bagi Guru-Guru Anggota MGMP Kimia dan Biologi Kota Padang Panjang”. INA-Rxiv. August 16. doi:10.31227/osf.io/yhau2. 
Zainul, R, \& Jannah, A. R. 2017. "Pengembangan Media Pembelajaran Asam Basa Menggunakan Aplikasi Android Berbasis Chemistry Triangle Kelas XI SMA/MA". February 6. doi:10.31227/osf.io/muh8y.

Zulkarnain, Andi., Nina Kadaritna., dan Lisa Tania. 2015. Pengembangan Emodul Teori Atom Mekanika Kuantum Berbasis WEB dengan Pendekatan Saintifik. Jurnal Pendidikan dan Pembelajaran Kimia. Volume 4, Nomor 1, Halaman 222-235. 